\title{
Pesticides Surveillance on Surface Waters: Developing a Method for Watersheds Prioritization
}

\author{
Carolina Menezes and Léo Heller \\ Universidade Federal de Minas Gerais \\ Brazil
}

\section{Introduction}

The occurrence of pesticides in drinking water is a matter of growing concern in several parts of the world, mainly in developing countries, due to the possible adverse effects on human health and the environment. Pesticides applied in the agriculture, important source of contamination, can persist for several years in soil, be retained in agricultural products, be dispersed by the wind or reach the surface and ground waters (Tomita \& Beyruth, 2003). Traces of pesticides can be found, both in soil and water sources, depending on their physical and chemical properties, their application and dose patterns, as well as the local environmental characteristics.

In Brazil, pesticide monitoring in surface water, both by water supply operators and health authorities, is still rare and insufficient for assessing health risks, often not accomplishing the legal issues regarding the quality control of raw waters (Brazil, 2004b). Inclusion of the whole set of these parameters in monitoring plans is unusual, mainly due to high costs of the analyses and to necessity of specialized manpower. There is also a lack of data on pesticides use in agriculture, in the several Brazilian regions, as well as of studies that associate their use with presence in water and with health risks. Additionally, low potential of pesticides removal in most of the Brazilian water treatment plants completes the picture of lack of reliable information on health risks associated with pesticides exposure by water ingestion.

The lack of data and of financial and material resources to comprehensive pesticide surveillance suggests tracing other alternatives to the evaluation of potentiality of pesticides occurrence in surface water. Thus, the aim of this chapter is to discuss a method for prioritization of surveillance actions of pesticides in surface waters, through multicriteria analysis. In the chapter, firstly we discuss concepts related to the subject. Secondly, the structure of the method is presented and, thirdly, we describe an application in Rio Grande basin, Minas Gerais, Brazil. Finally, we draw some conclusions on the study.

\section{Pesticides in water and health}

Health risks from exposure to pesticides, especially on child health, is a well known issue, with a number of epidemiological studies. These studies are consistently reporting increased 
risks between pesticide exposures and childhood leukemia, brain cancer, neuroblastoma, non-Hodgkin's lymphoma, Wilms' tumor, and Ewing's sarcoma (Infante-Rivard \& Weichenthal, 2001).

Studies have been developed focusing on the effects of pesticides in water on human health, particularly workers' health, however, with many gaps in knowledge of the relationship between pesticides and risks to human health, especially regarding presence of pesticides in water.

Although developed countries concentrate the bulk of pesticides consumption, most of poisonings and deaths caused by pesticides occurs in developing countries, and countries like Brazil shows an unsafe situation concerning human and environmental risks due to pesticides in water. This reality can have association with a combination of factors: excessive use of these substances; inadequate and unsafe occupational practices including inefficient use of personal protective equipment; low educational qualification of rural workers; improper labelling; inadequate or nonexistent infrastructure for washing utensils; improper handling of wastes and empty containers; use of containers for storing food and water; high productionist pressures from distributors and producers. A weak oversight of law enforcement, poor technical assistance to rural production and poor health care facilities complements the framework of health risks from pesticides in developing countries (FAO, 1999 apud Campanhola \& Bettiol, 2002; Moreira et al., 2002).

Water contamination by pesticides can result from numerous non-point sources and agriculture is identified as the largest contributor (Tomita \& Beyruth, 2003). Pesticides applied on agricultural crops can persist for several years in soil and can reach surface waters through superficial fluxes and leaching, contaminate groundwater by percolation, disperse in atmosphere or accumulate as residues in food. Regarding water contamination, when applied in agriculture, pesticides may reach surface water through transport dissolved in water or by transport associated with suspended sediment.

Understanding the behaviour and persistence of pesticides in the environment depends on knowledge of their specific chemical and physical properties; characteristics of their application vis-a-vis types of agricultural crops; environmental and climatic conditions (Brazil, 2002b; Luchini \& André, 2002; Martins et al., 2004). Depending on the characteristics of a particular pesticide, alone or associated with other substances, high degree of persistence, bioaccumulation and toxicity can be found (Martins et al., 2004).

Once reached the water source, persistence of pesticides in water and water characteristics, such as $\mathrm{pH}$, temperature, turbidity, suspended solids, flow and depth will determine the potential for ingestion of these micro contaminants (Kamrin, 1997 apud Martins et al., 2004). It is relevant to point out that some monitoring data may be poor indicators of water pollution by pesticides, mainly when substances are adsorbed to suspended solids. In this line, results reported as "undetectable" may be due to inadequate procedures, analysis or sampling. Values associated with sediments can be generally much higher than those recorded in water samples. Thus, difficulties in the evaluation and quantification of pesticides should not be neglected. A possible procedure, adopted by some water control agencies, is the use of various types of samples (water + sediment + biota), that could ensure obtaining more consistent results (D'Amato et al., 2002).

In some cases, there are difficulties for assessing the source and the when the pollution occurred, due to the persistence of pesticides. Their presence in water either may be the result of a recent discharge, of air transport over long distances after crops application, or a persistent residue remaining from a very old application. This is the case of DDT, for 
instance, which still can be found in many countries, although its use was officially prohibited several years ago (Rissato et al., 2006).

Regarding legislation for drinking water surveillance, there is not necessarily a standard procedure among countries, although international directives related to control of water quality, like the WHO guidelines and EU directives, have long been considered by several countries in their national policies for water and health promotion. However, translation of these international recommendations is not easily translated to national realities, for the establishment of drinking water standards or of surveillance procedures, given the complex nature of the concepts involved, the need of reliable research involved in the proposal and review them.

World Health Organization - WHO, through the 3rd edition of the Guidelines for DrinkingWater Quality, establishes guidelines on how to provide access to safe water and with acceptable risk to human health. Regarding pesticides, the document presents recommended limits for concentration of those most relevant and with evidenced health risks (WHO, 2004). In the EU, the European Directive No. 98/83 (European Council, 1998) establishes a limit of $0.1 \mu \mathrm{g} / \mathrm{L}$ as the maximum concentration level for any pesticide individually, $0.5 \mu \mathrm{g} / \mathrm{L}$ for total pesticides in drinking water and $1-3 \mu \mathrm{g} / \mathrm{L}$ in surface waters. In Brazil, Decree 518/2004 of the Ministry of Health (Brazil, 2004b), in establishing procedures and responsibilities related to control and surveillance of drinking water and quality standards, presents concentration limits of 22 pesticides, considered potential health hazards. Most of them consist of organochlorines, pyrethroids and organophosphates and only one carbamate. Moreover, this ordinance recommends identification of activity of the enzyme acetylcholinesterase, in order to assess the presence of organophosphate and carbamate insecticides in water.

Regarding monitoring, the referred Brazilian legislation establishes the minimum number and minimum frequency of samples for water quality control, depending on the sampling point, the population served and the type of source. For pesticides control, at least one sample every six months should be collected, in the effluent of the treatment plant, both for surface and groundwater sources. Systems supplied by surface water sources are due to raw water samples, each six months, for analysis according to the environmental legislation, assessing compatibility between raw water characteristics and the type of water treatment (Brazil, 2004b, Art. 29). Brazilian environmental legislation classifies surface water bodies, according to their uses and water quality requirements, and establishes standards for effluent discharge, setting limits for some pesticides, with close association with the Decree MS 518/2004.

Despite the potential risks associated to presence of pesticides in water and the scope of legislation on this subject, there is great deficiency in Brazil related to adequate control by water providers, and mainly surveillance by health authorities. Besides that, there is no formalised methodology for visioning priority basins, seeking at rationalising efforts in surveillance, based on land use and occupation; application practices; crop production or raw water quality.

\section{The method}

Decision-making on the best practices for water quality surveillance on pesticides presence is typically a complex situation, involving multiple stakeholders and factors. In cases like this, it is important that decision-making, involving multiple actors and multiple uses of 
water, consider the political, social, economic, financial, hydrological, environmental and engineering factors, among others, leading solutions that best reconcile interests and assumptions (Braga \& Gobetti, 2002).

Decision-making can be defined as an effort to solve the dilemma of conflicting objectives, whose presence prevents the existence of "optimal solution", leading in search of the "best solution agreement." The complexity of decision-making requires a qualified approach and justifies the use of methods for decision support. The multicriteria methods encompass tools for subsidizing the decision process, taking into account a number of different factors, from different analytical dimensions, through using of qualitative and/or quantitative approaches. They provide a basis for discussion, especially in cases of conflicts between decision-makers, contributing to an integrated analysis of a large number of data, interactions, and goals. On the other hand, as an inconvenience, there is a lack of an overall methodology, which overcomes all the limitations of each method (Vilas Boas, 2005).

As detection of several critical factors is crucial for selection of water systems with potential health risks from pesticides presence, we developed a sequence of steps looking for application of multicriteria method, based on a theoretical risk of contamination of surface waters by pesticides applied in agricultural areas, as follows:

Firstly, information on pesticides (toxicological and environmental classifications, physical and chemical properties, effects on human health and on the environment, etc) was gathered.

Then, a theoretical model was developed, aiming at explaining influences of the characteristics of the environment, as soil type, rain, hydrography, topography and particularities of agriculture practices, on the potential of pesticides dispersion in the environment and occurrence in surface waters. The key intervening factors were identified in the model and five of them were selected to feed the multicriteria analysis.

The multicriteria method adopted was the TOPSIS (Technique for Order Preference by Similarity to Ideal Solution), developed by Hwang and Yoon (1981 apud Pomerol \& BarbaRomero, 1993), which evaluates the distance in relation to an ideal and to an anti-ideal pattern, through a geometric notion of the best one. The solutions recommended are that closest to the ideal solution, by a proximity measure (Pomerol \& Barba-Romero, 1993; Braga \& Gobetti, 2002), according to the following equations:

- $\quad$ Distance to the ideal

$$
d_{p}^{M}\left(a_{i}\right)=\left[\sum_{j} w_{j}^{p *}\left|a_{j}^{M}-a_{i j}\right|^{p}\right]^{1 / p} \text { for } p \geq 1
$$

- Distance to the anti-ideal

$$
d_{p}^{m}\left(a_{i}\right)=\left[\sum_{j} w_{j}^{p *}\left|a_{j}^{m}-a_{i j}\right|^{p}\right]^{1 / p} \text { for } p \geq 1
$$

Based on the equations (1) and (2), the similarity rate is calculated by:

$$
D_{p}\left(a_{i}\right)=\frac{d_{p}^{m}\left(a_{i}\right)}{d_{p}^{M}\left(a_{i}\right)+d_{p}^{m}\left(a_{i}\right)}, \text { for } p \geq 1
$$

$d^{M}{ }_{p}\left(a_{i}\right)$ : distance of Minkovski between $a^{M_{i}}$ and $a_{i j}$; 
$d^{m_{p}}\left(a_{i}\right)$ : distance of Minkovski between $a^{m_{i}}$ and $a_{i j} ;$

$j:$ analyzed criterion;

$w_{j}$ : weight of $j$ criterion;

$a^{M_{\mathrm{j}}}$ : point of ideal of $j$ criterion (maximum value);

$a^{m_{i}}$ : point of anti-ideal of $j$ criterion (minimum value);

$a_{i j}$ : point of $i$ alternative and $j$ criterion;

$p$ : value that defines the distance type;

$D_{p}\left(a_{i}\right)$ : similarity rate;

$d^{M}{ }_{p}\left(a_{i}\right)$ : distance of Minkovski to ideal;

$d^{m}{ }_{p}\left(a_{i}\right)$ : distance of Minkovski to anti-ideal.

The value of $D_{p}$ varies from 0 , for the anti-ideal point, to 1 , for the ideal point. In this research two values of $p(p=1$ and $p=2)$ were considered.

By the similarity rate calculated for each system, the proposed solutions are ordered in a ascending list, in which the value closest to one, obtained in the similarity rate measure $D_{p}\left(a_{i}\right)$, corresponds to the best solution. For each of the five selected criteria a weight range was attributed, in a scale from 0 to 10 .

Next, the validation of the method was carried out by an application in five sub-basins of Grande River Basin, in Minas Gerais, Brazil: GD 3 (around Furnas's Dam), GD 4 (Verde River Basin), GD 5 (Sapucaí River Basin), GD 6 (Pardo River and Mogí-Guaçu River Basins), GD 7 (around Peixoto's Dam and Sapucaí Stream). The values of each criterion for each subbasin were obtained and, in order to develop a sensitive analysis, the weights were varied.

\section{Defining criteria and weights}

The method considered intrinsic factors related to the pesticides and environmental aspects, regarding the assessment and comparison of different potential of pesticide dispersion. Five factors were considered for the application of multicriteria analysis.

Selection and prioritization of sub-basins with higher potential risk considered weights for each alternative. Weighting for pesticides risk was based on a literature review, highlighting the major factors involved in persistence and mobility of pesticides in the environment.

The following sections present the criteria and assumptions adopted:

\subsection{Proportional cultivation area of the main agricultural cultures of the sub-basin.}

It was assumed that the larger the agricultural occupation in the sub-basin is, the bigger is the likelihood of pesticides use on agricultural crops.

The calculation of this factor considered the significant cultures existent in the sub-basin, both in terms of cultivated area, for the cultures that have the characteristic of demanding great areas, or in terms of cultures that demand smaller areas with great productivity or with possibility of high use of pesticides. The main crops in each selected sub-basin were identified, based on the extent of area per crop and their average productivity (data obtained in FAEMG, 2005). Monitoring Report of Surface Water in the Rio Grande Basin in 2004 (IGAM, 2005) provided information on total area of each sub-basins.

In order to establish a grade of importance for the different crops, we established an association between proportions of area covered by the crop and sub-basin area and the crop relevance for the specific sub-basin (Table 1).

Criterion for inclusion of the crop in the analyses considered those with classifications "main crop" and "less relevant crop". A range of weight from 8 to 9 was attributed to this criterion. 


\begin{tabular}{|l|c|c|c|}
\hline \multicolumn{1}{|c|}{ Crops } & $\begin{array}{c}\text { Main crop } \\
\mathbf{( \% )}\end{array}$ & $\begin{array}{c}\text { Less relevant crop } \\
\mathbf{( \% )}\end{array}$ & $\begin{array}{c}\text { Crop not } \\
\text { relevant (\%) }\end{array}$ \\
\hline Orange and tomato & $>0.1$ & $0.02-0.1$ & $<0.02$ \\
\hline $\begin{array}{l}\text { Rice, banana, potato and } \\
\text { sugar cane }\end{array}$ & $>0.5$ & $0.2-0.5$ & $<0.2$ \\
\hline Bean & $>1.0$ & $0.5-1.0$ & $<0.5$ \\
\hline Coffee and corn & $>4.0$ & $2.0-4.0$ & $<2.0$ \\
\hline
\end{tabular}

Table 1. Criteria for selection of the relevant cultures, in percentage of area by crop culture in sub-basins of Rio Grande.

\subsection{Proportion of group 1 pesticides.}

Group 1 pesticides reflects high potential of surface waters contamination through transport associated with sediment or dissolved in water. The probability of use of this group of pesticides in a certain watershed suggests high risk of deterioration of surface water quality regarding human consumption, according to the method of Goss (1992 apud Dores \& DeLamonica-Freire, 2001).

By the identification of the significant crops in each basin, and based on papers (Kammerbauer and Moncada, 1998; Larini, 1999; Laabs et al., 2000; Dores and De-LamonicaFreire, 2001; Cerejeira et al., 2003; Brazil, 2004a), it was possible to estimate, the pesticides of groups 1, 2 and 3 (high, medium and low potential of contamination of surface waters, respectively) likely to be applied and to calculate the proportion of those pesticides with potential use in each crop, for each potential group of contamination of surface waters. Thus, the representative value of the group 1 for each sub-basin was estimated by the average of the percentage of group 1 use, referring to each culture considered significant for the sub-basin. A range of weight from 7 to 9 was adopted for this factor, depending on the level of information available about which pesticides used on agricultural crops in each subbasin.

The lack of consistent information in governmental agencies about pesticides uses on agricultural crops had required consultation to other databases such the Pesticide Information System (Sistema de Informações sobre Agrotóxicos - ANVISA), which identifies the cultures allowed to apply of specific active ingredients and guidelines for pesticide application in agricultural crops.

\subsection{Proportion of municipal districts that have water treatment plants with techniques that allow at least partial removal of pesticides.}

The water treatment method influences considerably the drinking-water quality and the health risks, regarding the exposure to pesticides.

Conventional treatment (coagulation, flocculation, sedimentation and rapid filtration) does not ensure satisfactory performance in removal of most of pesticides. So, use of advanced treatment, such as adsorption by activated carbon or membrane filtration is recommended. These last types of water treatment techniques, however, are very seldom used in Brazil.

The criterion consists of the identification of proportions of water treatment techniques within the sub-basin that have at least some potential of pesticides removing, in order to qualitatively assessing risks to human health. The proportion was calculated in relation of the total number of municipalities in the basin. 
The likely lack of use of advanced techniques in water treatment plants in the municipalities of Rio Grande basin required adoption of an alternative approach, by consideration of plants with conventional treatment or direct filtration and plants with treatment level "less" than these techniques, due to the ability of the former to better removing suspended solids and, consequently, some pesticides associated. So, municipalities with simplified or conventional treatment would be in a safer situation than those without treatment or with single disinfection, regarding pesticides presence in drinking-water, even with differences in degree of raw water contamination.

The current techniques of treatment available in municipality of each sub-basin had been listed initially, based on information from the Water and Sanitation Company of Minas Gerais - COPASA, which attends most cities in the region, and from IBGE (2000), for those municipalities not provided by COPASA. The IBGE database provides the following categories for treatment process: "conventional treatment or non-conventional", "treatment with simple disinfection" and "no treatment". On the other side, COPASA database classifies the types of treatment in "conventional", "direct filtration" and "well with chlorination and fluoridation". Due to these divergent classifications, we considered the first category of IBGE and the two former categories of COPASA as "system with partial removal potential of pesticides" and the others as "system without conditions for pesticides' removal", as Table 2.

\begin{tabular}{|l|c|c|}
\hline Database & $\begin{array}{c}\text { Systems with partial removal } \\
\text { potential of pesticides }\end{array}$ & $\begin{array}{c}\text { Systems without conditions for } \\
\text { removal of pesticides }\end{array}$ \\
\hline COPASA & $\begin{array}{c}\text { "conventional"; } \\
\text { "direct filtration". }\end{array}$ & $\begin{array}{c}\text { "well with chlorination and } \\
\text { fluoridation". }\end{array}$ \\
\hline IBGE & $\begin{array}{c}\text { "conventional or non- } \\
\text { conventional treatment". }\end{array}$ & $\begin{array}{c}\text { "treatment with simple } \\
\text { disinfection"; } \\
\text { "no treatment". }\end{array}$ \\
\hline
\end{tabular}

Table 2. Grouping of the conditions of drinking water treatment.

As that factor influences positively the health risk, its value was inverted, in order to feed the analysis. A range weight from 4 to 5 was adopted.

\subsection{Medium slope of the sub-basin}

The topography of the basin, together with the soil type and vegetation, can interfere in the contaminants flow in the basin. The steeper the topography, the larger the run-off potential and the resulting transport of sediments to water sources.

The areas of each sub-basin can be analysed according to a range of slopes, varying from flat terrain to hilly. Table 3 presents the punctuation of the sub-basin according to the slope range value of the, in a scale from 1 to 5 .

\begin{tabular}{|l|c|c|}
\hline Relief class & Slope range & Score \\
\hline Flat & $<3 \%$ & 1 \\
\hline Mild wavy & 3 a $12 \%$ & 2 \\
\hline Wavy & 12 a $24 \%$ & 3 \\
\hline Highly wavy to hilly & 24 a $45 \%$ & 4 \\
\hline Hilly & $>45 \%$ & 5 \\
\hline
\end{tabular}

Table 3. Medium slope of the sub-basin punctuation according to the range of slopes 
Obviously, the greater the slope of a watershed, the greater the possibility of run-off and pesticides discharge in watercourses. In the study, the use of this criterion was based on information provided by the Water Management Institute of Minas Gerais - IGAM.

The range from 6 to 8 was considered for the weight.

\subsection{Annual maximum intensity of rain in the sub-basin}

When the period of application coincides with intense rains, the probability of carrying products in the watershed increases, requiring eventual reapplication, due to soil washing. Regarding this criterion, the annual maximum rain intensity measured in rain gauge stations was calculated in each sub-basin, through the software Hidro, available in the Brazilian Water National Agency (Agência Nacional das Águas - ANA) website.

In one hand, heavy rains cause carrying of larger amount of substances into groundwater or surface water, in the other, total rainfall contributes to the dissolution of these substances, reducing its concentration in the watercourse. Due to these considerations, the maximum annual precipitation in each sub-basin was adopted. A range of weights from 6 to 8 was attributed.

Table 4 summarises the selected criteria list and their range of weights.

\begin{tabular}{|c|l|c|}
\hline & Criteria & $\begin{array}{c}\text { Weight } \\
(w)\end{array}$ \\
\hline I & $\begin{array}{l}\text { Proportional cultivation area of the main agricultural cultures of the } \\
\text { sub-basin. }\end{array}$ & 8 to 9 \\
\hline II & Proportion of group 1 pesticides. & 7 to 9 \\
\hline III & $\begin{array}{l}\text { Proportion of municipal districts that have water treatment plants } \\
\text { with techniques that allow at least partial removal of pesticides. }\end{array}$ & 4 to 5 \\
\hline IV & Medium slope of the sub-basin. & 6 to 8 \\
\hline V & Annual maximum intensity of rain in the sub-basin. & 6 to 8 \\
\hline
\end{tabular}

Table 4. Selected criteria and range of weight

All the criteria, except criterion III, can increase the potentiality of pesticides contamination in the sub-basin, as the respective weight increases.

\section{Application in Rio Grande Basin, Brazil}

Rio Grande basin, located in the southern region of Minas Gerais, state at the Southeast Region of Brazil, presents a profile of important agricultural producer and has a cluster of agricultural crops, among the selected in this study, in nearby areas. Comparing the region with other similar in the state of Minas Gerais, based on agricultural practices, the South Region seems to produce crops with highest potential for health risks in water, and for this reason was chosen for the study.

Through research of the municipalities in southern Minas Gerais with highest crop production and productivity, we identified five sub-basins for study. These sub-basins are part of the Rio Grande Basin, sub-basin of the Paraná River Basin. The Rio Grande has a length of $1,360 \mathrm{~km}$ and the basis has $143,000 \mathrm{~km}^{2}$.

The application of the method for the five sub-basins of the Grande River Basin, selected for study, resulted in a priority order for surveillance of pesticides presence in surface waters. 
Table 5 lists these sub-basins, indicating the most cultivated crops within its coverage area in order to facilitate evaluation of potential risk from pesticide use in their production.

\begin{tabular}{|c|l|c|c|c|}
\hline \multicolumn{2}{|c|}{ Sub-basins } & Main crops & $\begin{array}{c}\text { Other relevant } \\
\text { crops }\end{array}$ & $\begin{array}{c}\text { Other } \\
\text { considered crops }\end{array}$ \\
\hline GD 3 & $\begin{array}{l}\text { Around Furnas } \\
\text { Reservoir }\end{array}$ & $\begin{array}{l}\text { Potato, coffee, sugar } \\
\text { cane, bean and corn. }\end{array}$ & $\begin{array}{c}\text { Rice, orange and } \\
\text { tomato. }\end{array}$ & Banana. \\
\hline GD 4 & Verde River Basin & $\begin{array}{c}\text { Potato, coffee, bean } \\
\text { and corn. }\end{array}$ & Banana. & $\begin{array}{c}\text { Sugar cane and } \\
\text { tomato. }\end{array}$ \\
\hline GD 5 & $\begin{array}{l}\text { Sapucaí River } \\
\text { Basin }\end{array}$ & $\begin{array}{c}\text { Banana, potato, } \\
\text { coffee, bean and corn. }\end{array}$ & $\begin{array}{c}\text { Rice, orange and } \\
\text { tomato. }\end{array}$ & Sugar cane. \\
\hline GD 6 & $\begin{array}{l}\text { Pardo River and } \\
\text { Mogi-Guaçu River } \\
\text { Basins }\end{array}$ & $\begin{array}{c}\text { Potato, coffee, sugar } \\
\text { cane and corn. }\end{array}$ & Bean. & Banana e tomato. \\
\hline GD 7 & $\begin{array}{l}\text { Around Peixoto's } \\
\text { Reservoir and } \\
\text { Sapucaí Stream }\end{array}$ & $\begin{array}{r}\text { Coffee, sugar cane } \\
\text { and corn. }\end{array}$ & $\begin{array}{c}\text { Rice, bean e } \\
\text { orange. }\end{array}$ & Potato and \\
tomato.
\end{tabular}

Table 5. Pre-selection of sub-basins of the Rio Grande Basin - MG.

$\mathrm{GD}=$ Term used by IGAM for sub-basins of the Rio Grande Basin.

Sources: FAEMG, 2005; IGAM, 2005.

Sub-basins GD 3, GD and GD 45 converge to Furnas Reservoir and sub-basin GD 7 to Peixoto's Reservoir, both built for energy generation. Regarding the sub-basin GD 6, it is part of the basin of Mogi Guaçu, in Sao Paulo State.

Classification of pesticides potentially used in the basin resulted in grouping in high, medium and low potential for contamination of surface waters, according to the method of Goss (1992), as shown in Table 6.

\begin{tabular}{|c|c|c|c|}
\hline $\begin{array}{c}\text { Potential of } \\
\text { surface water } \\
\text { contamination }\end{array}$ & High & Medium & Low \\
\hline $\begin{array}{c}\text { Associated with } \\
\text { the sediment } \\
\text { transported in } \\
\text { suspension }\end{array}$ & $\begin{array}{c}\text { Chlorpyrifos, } \\
\text { endosulfan, } \\
\text { glyphosate, lindane, } \\
\text { pendimethalin, } \\
\text { trifluralin }\end{array}$ & $\begin{array}{c}\text { Aldrin, atrazine, DDT, } \\
\text { heptachlor, metolachlor, } \\
\text { parathion-methyl, } \\
\text { permethrin, simazine }\end{array}$ & $\begin{array}{c}\text { 2,4-D, alachlor, } \\
\text { bentazone, cyanazine, } \\
\text { dieldrin, } \\
\text { hexachlorobenzen, } \\
\text { malathion, } \\
\text { methoxychlor, } \\
\text { molinate, propanil }\end{array}$ \\
\hline $\begin{array}{c}\text { Dissolved in } \\
\text { water }\end{array}$ & $\begin{array}{c}\text { Aldicarb, atrazine, } \\
\text { carbofuran, lindane, } \\
\text { simazine }\end{array}$ & $\begin{array}{c}\text { 2,4-D, alachlor, cyanazine, } \\
\text { chlorpyrifos, glyphosate, } \\
\text { malathion, metolachlor, } \\
\text { molinate, parathion- } \\
\text { methyl, trifluralin }\end{array}$ & $\begin{array}{c}\text { Chlordane, endrin, } \\
\text { endosulfan, } \\
\text { permethrin }\end{array}$ \\
\hline
\end{tabular}

Table 6. Grouping of pesticides based on the method of Goss.

Sources: WHO, 2004; BRASIL, 2004a; GOSS, 1992 (apud DORES and DE-LAMONICA-FREIRE, 2001) 
According to Goss criteria, pesticides applied in agriculture, regarding their potential to reach surface water, can be classified in those that can be transported dissolved in water and those associated with the sediment transported in suspension.

Figure 1 illustrates the proportion of group 1 pesticides (high potential for contamination of surface waters) used in the five sub-basins of the Rio Grande - MG, stratified with those possibly spread dissolved in water and those that may be associated with sediment transport. This information was used to application of criterion II.

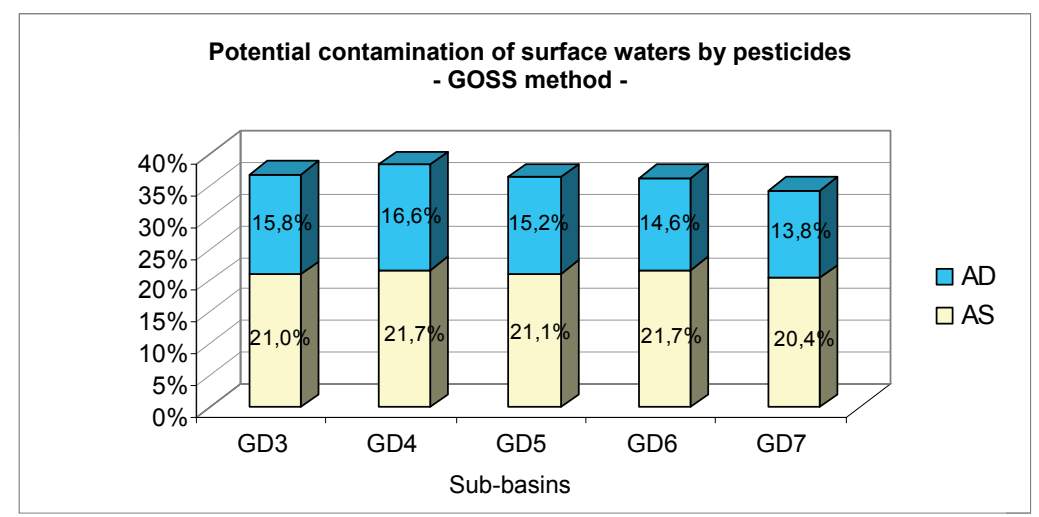

$\mathrm{AD}=$ high potential for transport dissolved in water, $\mathrm{AS}=$ high potential for transport associated with sediment.

Fig. 1. Proportion of pesticide use group 1 (high potential for contamination of surface waters) in sub-basins of the Rio Grande - MG.

Sources: KAMMERBAUER \& MONCADA, 1998; LARINI, 1999; LAABS et al., 2000; DORES \& DELAMONICA-FREIRE, 2001; BRASIL, 2002; CEREJEIRA et al., 2003; BRASIL, 2004a; MARTINS e tal., 2004; MINAS GERAIS, 2004; IGAM, 2005; FAEMG, 2005.

According to the crops identified as the main crops in each sub-basin, we can identify a proportion of $34 \%$ to $39 \%$ of pesticides group 1 - high contamination potential of surface water. The largest part of these pesticides relates to the potential of association with sediments. There is no high variation of this potential contamination between sub-basins, except for GD 4.

Table 7 shows the proportion of municipalities that have water treatment plants that ensure at least partial removal of pesticides and those without potential for removal of pesticides, as defined in Criterion III.

Out of 138 municipalities surveyed, near $85 \%$ has a potential for removal of pesticides at least partially. It can be highlighted that sub-basin GD 6, in the region of rivers Pardo and Mogi-Guaçu, stands out with a more favourable condition in terms of water treatment, while sub-basin GD 4 shows the lowest percentage of cities with potential to at least partial removal of pesticides.

Regarding the criterion IV, Table 8 shows the scores adopted in each sub-basin of the Rio Grande - MG, based on ranges of average slopes of the land.

Sub-basins GD 3 and GD 7 have low average slope, which is coherent with the fact of including areas near or inside reservoirs. Sub-basins GD 5 and GD 6, on the other hand, have an average slope steeper compared to the other sub-basins, with classes of relief from 


\begin{tabular}{|c|c|c|c|c|}
\hline \multirow{3}{*}{ Sub-basin } & \multicolumn{4}{|c|}{ Pesticides potential removal } \\
\cline { 2 - 5 } & \multicolumn{2}{|c|}{ Partial potential } & \multicolumn{2}{c|}{ No potential } \\
\cline { 2 - 5 } & municipalities & $\%$ & municipalities & $\%$ \\
\hline GD3 & 30 & $83.3 \%$ & 6 & $16.7 \%$ \\
\hline GD4 & 18 & $78.3 \%$ & 5 & $21.7 \%$ \\
\hline GD5 & 35 & $85.4 \%$ & 6 & $14.6 \%$ \\
\hline GD6 & 19 & $95.0 \%$ & 1 & $5.0 \%$ \\
\hline GD7 & 15 & $83.3 \%$ & 3 & $16.7 \%$ \\
\hline Total & 117 & $84.8 \%$ & 21 & $15.2 \%$ \\
\hline
\end{tabular}

Table 7. Proportion of municipalities of Minas Gerais with the potential removal of pesticides, by sub-basin of the Rio Grande - MG

Sources: IGAM, 2005, COPASA, 2005; IBGE, 2000.

\begin{tabular}{|l|c|c|c|c|c|}
\hline $\begin{array}{l}\text { Average slope of the } \\
\text { sub-basin }\end{array}$ & GD3 & GD4 & GD5 & GD6 & GD7 \\
\hline Range slope & 12 to $24 \%$ & 12 to $24 \%$ & 24 to $45 \%$ & 24 to $45 \%$ & 3 to $12 \%$ \\
\hline Score & 3 & 3 & 4 & 4 & 2 \\
\hline
\end{tabular}

Table 8. Average slope of the sub-basins of the Rio Grande - MG.

Source: IGAM, 2006.

\begin{tabular}{|c|c|c|c|c|c|c|c|}
\hline \multirow{2}{*}{ Criteria } & \multirow{2}{*}{ Un. } & \multirow{2}{*}{ Weight } & \multicolumn{6}{|c|}{ Sub-basins } \\
\cline { 4 - 8 } & & & $\mathbf{3}$ & $\mathbf{4}$ & $\mathbf{5}$ & $\mathbf{6}$ & $\mathbf{7}$ \\
\hline I & $\%$ & 8 & 27.71 & 15.11 & 13.88 & 18.66 & 14.65 \\
\hline II & $\%$ & 7 & 38.08 & 39.74 & 37.45 & 36.74 & 34.94 \\
\hline III & $\%$ & 4 & 75.00 & 69.57 & 65.85 & 85.00 & 83.33 \\
\hline IV & - & 6 & 3 & 3 & 4 & 4 & 2 \\
\hline V & $\mathrm{mm}$ & 7 & 80.15 & 76.13 & 75.88 & 76.74 & 73.58 \\
\hline
\end{tabular}

Table 9. Scoring and weighting of criteria for each sub-basin.

Source: IBGE, 2000; ANA, 2005; BRASIL, 2002; BRASIL, 2004a; MARTINS et al., 2004; COPASA, 2005;

FAEMG, 2005; IGAM, 2005; IGAM, 2006.

strongly wavy to hilly. Analyzing criterion IV, sub-basins GD5 and GD6 have higher potential for dispersal of pesticides within their basins, with possibility of contamination of surface waters.

Criterion V, in turn, considers the influence of rainfall on the potential dispersal of pollutants in the environment. Sub-basin GD 3 shows the highest maximum annual rainfall among the selected areas.

Table 9 summarises values obtained in each sub-basin for each of the five criteria, and the weight given to the criteria considered in multicriteria analysis.

Table 10 shows the final values for each criterion in each of the five sub-basins, together with their respective weights parameterized, and the values for the "ideal" and "antiideal." 


\begin{tabular}{|c|c|c|c|c|c|c|c|c|}
\hline \multirow{2}{*}{ Criteria } & \multirow{2}{*}{ Weight } & \multicolumn{5}{|c|}{ Sub-basins } & \multirow{2}{*}{ Ideal } & \multirow{2}{*}{$\begin{array}{l}\text { Anti- } \\
\text { ideal }\end{array}$} \\
\hline & & 3 & 4 & 5 & 6 & 7 & & \\
\hline I & 0.250 & 0.319 & 0.165 & 0.152 & 0.204 & 0.160 & 0.319 & 0.152 \\
\hline II & 0.219 & 0.202 & 0.211 & 0.200 & 0.200 & 0.188 & 0.211 & 0.188 \\
\hline III & 0.125 & 0.206 & 0.214 & 0.226 & 0.175 & 0.179 & 0.226 & 0.175 \\
\hline IV & 0.188 & 0.188 & 0.188 & 0.250 & 0.250 & 0.125 & 0.250 & 0.125 \\
\hline $\mathrm{V}$ & 0.219 & 0.210 & 0.199 & 0.198 & 0.201 & 0.192 & 0.210 & 0.192 \\
\hline
\end{tabular}

Table 10. Identification of Ideal and Anti-ideal for each criterion and each sub-basin.

Finally, Table 11 shows sub-basins ordering for pesticides surveillance in surface waters, based on the application of the multicriteria method.

\begin{tabular}{|c|c|c|c|c|c|c|c|c|}
\hline \multirow{2}{*}{$\begin{array}{c}\text { Sub- } \\
\text { basin }\end{array}$} & \multicolumn{4}{|c|}{$p=\mathbf{1}$} & \multicolumn{4}{|c|}{$p=\mathbf{2}$} \\
\cline { 2 - 9 } & $\mathbf{d}_{\mathbf{1}}\left(\mathbf{a}_{\mathbf{i}}\right)$ & $\mathbf{d}_{\mathbf{1}}\left(\mathbf{a}_{\mathbf{i}}\right)$ & $\mathbf{D}_{\mathbf{1}}\left(\mathbf{a}_{\mathbf{i}}\right)$ & TOPSIS & $\mathbf{d}_{\mathbf{M}_{\mathbf{1}}\left(\mathbf{a}_{\mathbf{i}}\right)}$ & $\mathbf{d}_{\mathbf{1}}\left(\mathbf{a}_{\mathbf{i}}\right)$ & $\mathbf{D}_{\mathbf{1}}\left(\mathbf{a}_{\mathbf{i}}\right)$ & TOPSIS \\
\hline GD 3 & 1,608 & 6,411 & 0.800 & $\mathbf{1}$ & 1,213 & 4,375 & 0.783 & $\mathbf{1}$ \\
\hline GD 4 & 5,397 & 2,621 & 0.327 & $\mathbf{4}$ & 4,029 & 1,407 & 0.259 & $\mathbf{4}$ \\
\hline GD 5 & 4,649 & 3,370 & 0.420 & $\mathbf{3}$ & 4,183 & 2,446 & 0.369 & $\mathbf{3}$ \\
\hline GD 6 & 3,947 & 4,071 & 0.508 & $\mathbf{2}$ & 2,961 & 2,695 & 0.476 & $\mathbf{2}$ \\
\hline GD 7 & 7,776 & 243 & 0.030 & $\mathbf{5}$ & 4,689 & 204 & 0,042 & $\mathbf{5}$ \\
\hline
\end{tabular}

Table 11. Hierarchy of systems by TOPSIS method $(\mathrm{p}=1$ and $\mathrm{p}=2)$.

Figure 2 presents the descriptive statistics of the values of the similarity rate - D , considering 108 possibilities, for each value of $p(p=1$ and $p=2)$. It can be observed that, for $p=1$, the values of similarity rate of the sub-basin GD 3 are closer to the unit (average of 0.789 ) and that this value disagrees with the other sub-basins. The sub-basins GD 5 and GD 6 present a common range of values, between 0.45 and 0.50 . Regarding sub-basin GD 7, the $\mathrm{D} p$ values are significantly below the others and present smaller standard deviation. The sub-basin GD 5 presents the highest standard deviation, of 0.0247 .

Comparing the diagrams presented in Figure 2, it can also be observed that the values of the similarity rate for $p=1$ present smaller standard deviation than when $p=2$. D $p$ values for the sub-basins GD 4 (Verde River Basin), GD 5 (around Furnas's Dam) and GD 6 (Pardo River and Mogí-Guaçu River Basins) are closer among themselves in $p=1$ than in $p=2$.

Despite the simulation with 108 possibilities, significant differences between the results were not observed, demonstrating the stability of the method.

At the end, multicriteria analysis by the method TOPSIS allowed the hierarchy of sub-basins studied in terms of priority for surveillance the presence of pesticides in water, as shown in Table 12. 

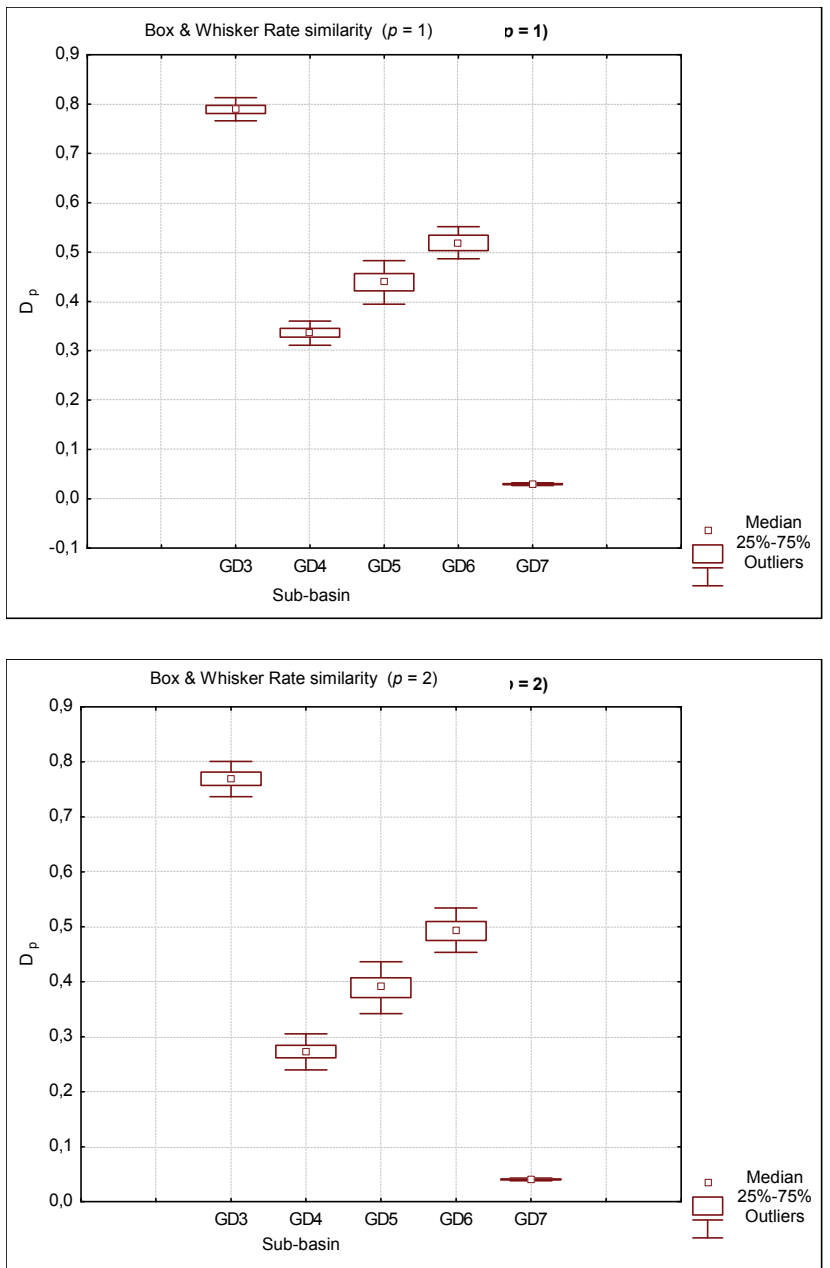

Fig. 2. Box \& Whisker Rate similarity - Dp, for $p=1$ and $p=2$.

\begin{tabular}{|c|c|}
\hline Priority & Sub-basin \\
\hline 1 & GD 3 \\
\hline 2 & GD 6 \\
\hline 3 & GD 5 \\
\hline 4 & GD4 \\
\hline 5 & GD 7 \\
\hline
\end{tabular}

Table 12. Prioritization of sub-basins of the Rio Grande - MG to monitoring the presence of pesticides in water. 


\section{Conclusion}

The method for prioritization of pesticides surveillance in surface waters looks at intrinsic factors of the active ingredients and environmental factors that could influence in the dynamics of the pesticides in the environment and human health risks.

The application of the method in the south area of Minas Gerais allowed the ordering of priority sub-basins for pesticides surveillance, suggesting sub-basins GD 3 (around Furnas's Dam) and GD 6 (Pardo River and Mogi-Guaçu River Basins) as priorities. The validation performed enabled the evaluation and adjustment of the method, mainly regarding the availability of information. Another issue revealed by this application is the need of generating information to best feed the model and improve its outcomes.

The method showed as a practical alternative for the environmental surveillance, targeting priority areas, which is important in realities with limitations of technical, material or personnel resources. Moreover, its structure allows the application in other different areas and for other pollutants.

Difficulty in data gathering was observed, associated with dispersion of information in different public and private organizations. This situation is critical to fill the failures in planning environmental surveillance, particularly on drinking-water quality. Another crucial issue the research points out is the lack of effective integration among the public sectors with interface with the problem - health, water supply, water resources, agriculture - in order to ensure an adequate epidemiological and environmental surveillance of pesticides in water.

\section{References}

Agência Nacional de Águas - ANA. (2005). Hidroweb - Sistema de Informações Hidrológicas. http://hidroweb.ana.gov.br/ (accessed 25 feb. 2006).

Braga, B. \& Gobetti, L. (2002). Análise multiobjetivo. In: PORTO, RL. (org.) Técnicas quantitativas para o gerenciamento de recursos hídricos. UFRGS (ed.), 2nd edn, Porto Alegre, Brazil. cap. 7, pp. 361-420.

Brazil (2002). Ministério da Agricultura, Pecuária e Abastecimento. Empresa Brasileira de Pesquisa Agropecuária - EMBRAPA Cerrados. Potencial de impacto da agricultura sobre os recursos hídricos na região do Cerrado. Documento 56. Dec., 2002.

Brazil (2004a). Ministério da Saúde. Agência Nacional de Vigilância Sanitária. Sistema de informações sobre agrotóxicos. http://www4.anvisa.gov.br/agrosia/asp/default.asp.

Brazil (2004b). Ministério da Saúde. Portaria n. 518, de 23 de março de 2004. Estabelece os procedimentos e responsabilidades relativas ao controle e vigilância da qualidade da água para consumo humano e seu padrão de potabilidade, e dá outras providências. http://www.funasa.gov.br/ sitefunasa/legis/pdfs/portarias_m/pm1518_2004.pdf (accessed 25 oct. 2004).

Campanhola, C.; Bettiol, W. (2002). Panorama sobre o uso de agrotóxicos no Brasil. In: Ministério do Meio Ambiente (org.). Fórum Nacional de Secretários de Agricultura. Programa de Defesa Ambiental Rural - textos orientadores.

Cerejeira, M.J.; Viana, P.; Batista, S.; Pereira, T.; Silva, E.; Valério, M. J.; Silva, A.; Ferreira, M. \& Silva-Fernandes, A.M. (2003). Pesticides in Portuguese surface and ground waters. Water Research, (37), 1055-1063. 
Companhia de Saneamento de Minas Gerais - COPASA (2005). Tipos de técnicas de tratamento de água por município operado pela COPASA.xls. Belo Horizonte.

D'amato, C.; Torres, J. P. M.; Malm, O. (2002). DDT (Dicloro Difenil Tricloroetano): toxicidade e contaminação ambiental - uma revisão. Química Nova, v. 25, n. 6, p. 995-1002.

Dores, E.F.G. \& De-Lamonica-Freire, E.M. (2001). Contaminação do ambiente aquático por pesticidas. Estudo de caso: Águas usadas para consumo humano em Primavera do Leste, Mato Grosso - Análise preliminar. Química Nova, (24)2, 27-36.

European Council (1998). Council Directive 98/83/EC of 3 November 1998 on the quality intended for human consumption. Official Journal of the European Comunities. L 330, p. 32-54.

Federação da Agricultura e Pecuária do Estado de Minas Gerais - FAEMG (2005). Informações sobre o setor. Dados de 2000 a 2004. http://www.faemg.org.br/ (accessed 15 aug. 2005).

Food and Agriculture Organization of the United Nations - FAO (1999). Guidelines for the management of small quantities of unwanted and absolete pesticides. Roma: FAO, 1999. 25p. (Boletim de Pesquisa, 2) apud Campanhola, C.; Bettiol, W. Panorama sobre o uso de agrotóxicos no Brasil. In: Ministério do Meio Ambiente (org.). Fórum Nacional de Secretários de Agricultura (2002). Programa de Defesa Ambiental Rural textos orientadores.

Goss, D.W. (1992). Screening procedure for soils and pesticides for potential water quality impacts. Weed Technology, (6)3, 701-708 apud Dores, E.F.G. \& De-Lamonica-Freire, E.M. (2001). Contaminação do ambiente aquático por pesticidas. Estudo de caso: Águas usadas para consumo humano em Primavera do Leste, Mato Grosso Análise preliminar. Química Nova. (24)2, 27-36.

Hwang, C. \& Yoon, K. (1981). Multiple attribute decision making. Methods and applications survey. Springer apud Pomerol, J-C. \& Barba-Romero, S. (1993). Choix multicritère dans l'entreprise - principes et pratique. Hermès, Paris.

Infante-Rivard, C. \& Weichenthal, S. (2007). Pesticides and childhood cancer: an update of Zahm and Ward's 1998 review. Journal of Toxicology and Environmental Health, Part $B, 10,81-99,2007$, ISSN: 1093-7404 print / 1521-6950 online

Instituto Brasileiro de Geografia e Estatística - IBGE (2000). Programa Nacional De Saneamento Básico - PNSB. Controle de qualidade na captação de água procedente de adutora de água bruta, segundo os distritos-sede dos municípios - Minas Gerais 2000. http://www.fjp.gov.br/produtos/cei/saneamento/Agua/AGUA-Tabela_5.1.xls (accessed 12 mar. 2006).

Instituto Mineiro de Gestão das Águas - IGAM (2000). Unidades de planejamento e de gestão dos recursos hídricos do estado de minas gerais. www.ana.gov.br/.../MG/ Outros/unidades\%20planejamento\%20tabela\% 20final.doc (accessed 5 june 2006).

Instituto Mineiro de Gestão das Águas - IGAM (2005). Relatório de monitoramento das águas superficiais na bacia do Rio Grande em 2004 / Instituto Mineiro de Gestão das Águas. IGAM, Belo Horizonte.

Kammerbauer, J. \& Moncada, J. (1998). Pesticide residue assessment in three selected agricultural production systems in the Choluteca River Basin of Honduras. Environmental Pollution, (103), 171-181. 
Kanrim, M. A. (1997). Pesticides profiles: Toxicity Environmental Impact and Fate. Florida, USA: Lewis Publishers apud Martins, M. D., Fernandes, C. S., Valente, J. T. Water contamination by pesticides. Case study: pesticides research in the Lower Cávado River Basin. In: World Water Congress, 4, 2004, Marrakesh. [Anais eletrônicos...] Marrakesh: IWA, 2004. 1 CD-ROM.

Laabs, V.; Amelung, W.; Pinto, A.; Altstaedt, A. \& Zech W. (2000). Leaching and degradation of corn and soybean pesticides in an Oxisol of the Brasilian Cerrados. Chemosphere, (41), 1441-1449.

Larini, L. (1999). Toxicologia dos Praguicidas. Manole, São Paulo.

Luchini, L. C.; Andréa, M. M. de (2002). Dinâmica de agrotóxicos no ambiente. In: Brasil. Ministério do Meio Ambiente (org.). Fórum Nacional de Secretários de Agricultura. Programa de Defesa Ambiental Rural - textos orientadores.

Martins, M.D.; Fernandes, C.S. \& Valente, J.T. (2004). Water contamination by pesticides. Case study: pesticides research in the Lower Cávado River Basin. In: World Water Congress, 4, 2004, Marrakesh. [Proceedings...] IWA, Marrakesh. 1 CD-ROM.

Minas Gerais (2004). Secretaria de Estado da Agricultura, Pecuária e Abastecimento. Empresa de Assistência Técnica e Extensão Rural do Estado de Minas Gerais EMATER. Principais agrotóxicos aplicados por cultura. Mimeografado.

Moreira, J. C.; Jacob, S. C.; Peres, F.; Lima, J. S.; Meyer, A.; Oliveira-Silva, J. J.; Sarcinelli, P. N.; Batista, D. F.; Egler, M.; Faria, M. V. C.; Araújo, A. J. de; Kubota, A. H.; Soares, M. De O.; Alves, S. R.; Moura, C. M.; Curi, R. (2002). Avaliação integrada do impacto do uso de agrotóxicos sobre a saúde humana em comunidade agrícola de Nova Friburgo, RJ. Ciência E Saúde Coletiva, v. 7, n. 2, p. 299-311.

Pomerol, J-C \& Barba-Romero, S. (1993). Choix multicritère dans l'entreprise - principes et pratique. Hermès, Paris.

Rissato, S.R.; Galhiane, M.S.; Ximenes, V.F.; Andrade, R.M.B.; Talamoni, J.L.B; Almeida, M.V. \& Libânio, M. (2006). Organochlorine pesticides and polychlorinated biphenyls in soil and water samples in the Northeastern part of São Paulo State, Brazil. Chemosphere (Oxford), Vol. 65, No. 11, p. 1949-1958.

Tomita, R.Y. \& Beyruth, Z. (2003). Toxicologia de agrotóxicos em ambiente aquático. $O$ Biológico. São Paulo, (64)2, 135-142. http://www.geocities.com/ esabio /tomita.htm (accessed 25 may 2004).

Vilas Boas, C. L. (2005). Análise da Aplicação de métodos multicritérios de apoio à decisão (MMAD) na gestão de recursos hídricos. In: Simpósio Brasileiro De Recursos Hídricos, 16, João Pessoa. [Proceedings...] João Pessoa: ABRH, 2005. 1 CD-ROM

World Health Organization - WHO. (2004). Guidelines for Drinking-water Quality. 3ed., v. 1. 


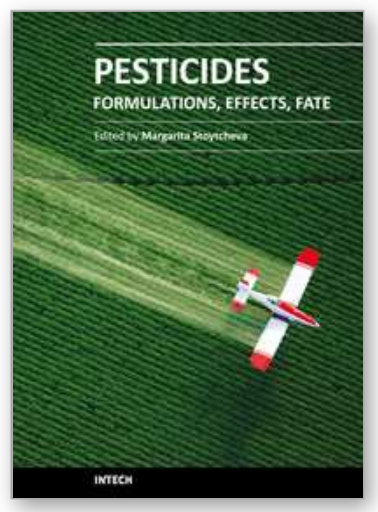

\author{
Pesticides - Formulations, Effects, Fate \\ Edited by Prof. Margarita Stoytcheva
}

ISBN 978-953-307-532-7

Hard cover, 808 pages

Publisher InTech

Published online 21, January, 2011

Published in print edition January, 2011

This book provides an overview on a large variety of pesticide-related topics, organized in three sections. The first part is dedicated to the "safer" pesticides derived from natural materials, the design and the optimization of pesticides formulations, and the techniques for pesticides application. The second part is intended to demonstrate the agricultural products, environmental and biota pesticides contamination and the impacts of the pesticides presence on the ecosystems. The third part presents current investigations of the naturally occurring pesticides degradation phenomena, the environmental effects of the break down products, and different approaches to pesticides residues treatment. Written by leading experts in their respective areas, the book is highly recommended to the professionals, interested in pesticides issues.

\title{
How to reference
}

In order to correctly reference this scholarly work, feel free to copy and paste the following:

Carolina Menezes and Léo Heller (2011). Pesticides Surveillance on Surface Waters: Developing a Method for Watersheds Prioritization, Pesticides - Formulations, Effects, Fate, Prof. Margarita Stoytcheva (Ed.), ISBN: 978-953-307-532-7, InTech, Available from: http://www.intechopen.com/books/pesticides-formulations-effectsfate/pesticides-surveillance-on-surface-waters-developing-a-method-for-watersheds-prioritization

\section{INTECH}

open science | open minds

\section{InTech Europe}

University Campus STeP Ri

Slavka Krautzeka 83/A

51000 Rijeka, Croatia

Phone: +385 (51) 770447

Fax: +385 (51) 686166

www.intechopen.com

\section{InTech China}

Unit 405, Office Block, Hotel Equatorial Shanghai

No.65, Yan An Road (West), Shanghai, 200040, China

中国上海市延安西路65号上海国际贵都大饭店办公楼 405 单元

Phone: +86-21-62489820

Fax: $+86-21-62489821$ 
(C) 2011 The Author(s). Licensee IntechOpen. This chapter is distributed under the terms of the Creative Commons Attribution-NonCommercialShareAlike-3.0 License, which permits use, distribution and reproduction for non-commercial purposes, provided the original is properly cited and derivative works building on this content are distributed under the same license. 